\title{
PENGELOLAAN KEUANGAN DAN ASET DAERAH DENGAN MENGGUNAKAN SISTEM APLIKASI (STUDI KASUS APLIKASI SIMDA KEUANGAN DAN SIMDA BMD)
}

\author{
Andhika Ramanda, Safuan, Musa Alkadhim Alhabshy \\ Universitas Jayabaya, Jakarta, Indonesia \\ Email: andhikaramanda@gmail.com, safuan@jayabaya.ac.id, musa.dosen@pascajayaba \\ ya.ac.id
}

\begin{abstract}
Abstrak
Pengelolaan keuangan daerah yang baik ditandai dengan di terbitkannya laporan keuangan yang baik, yang berarti memiliki relevansi, bisa dimengerti, bisa dibandingkan serta bisa diuji, netral, penyusunan laporan keuangan yang tepat waktu, dan lengkap. Untuk mencapai kriteria diatas dibutuhkan tools yang tepat, antara lain SDM yang berkompetensi, pemantauan berkesinambungan selama setahun penuh, dan juga untuk melengkapi dibutuhkan juga program aplikasi pengelolaan keuangan daerah. Sistem Informasi Manajemen Daerah (SIMDA) adalah salah satu program komputer yang banyak digunakan Pemerintah, khususnya Pemerintah Daerah, aplikasi ini mencakup penganggaran, yang merupakan awal dari pengelolaan keuangan daerah, penatausahaan, yang merupakan alat kontrol pengeluaran daerah selama setahun penuh, dan juga output berupa laporan-laporan yang berguna untuk kepentingan keuangan pemerintah daerah seperti Buku Besar, serta laporan keuangan diantaranya Neraca, Laporan Realisasi Anggaran, Laporan Arus Kas. Metode yang dipakai adalah penelitian kualitatif serta pendekatan studi kasus. Subjek dalam jurnal ini adalah narasumber, dengan objeknya yaitu Sistem Informasi Manajemen Daerah (SIMDA) Keuangan dan SIMDA BMD. Narasumber dalam penelitian ini yaitu unsur pemakai aplikasi. SIMDA Keuangan dan SIMDA BMD dibuat dengan harapan agar Pemerintah Daerah dapat terbantu dalam menyusun Laporan Keuangan dan Laporan Aset melalui media teknologi informasi, dengan proses otomatisasi yang terdapat dalam aplikasi SIMDA Keuangan yang dimulai dari perencanaan yaitu dengan dibuatnya Rencana Kerja Anggaran (RKA) lalu dilanjutkan dengan Dokumen Pelaksanaan Anggaran, lalu Penatausahaan Keuangan ddengan dibuatnya Surat Penyediaan Dana (SPD) yang dilanjutkan dengan pembuatan Surat Permintaan Pembayaran (SPP) kemudian Surat Perintah Membayar (SPM) dengan Surat Pertanggungjawaban (SPJ) yang diakhiri dengan Surat Perintah Pencairan Dana (SP2D) dan berakhir pada proses akuntansi dengan melakukan posting terhadap jurnal-jurnal yang timbul karena proses penatausahaan serta proses yang ada pada SIMDA BMD dapat dilihat pada proses Perencanaan aset, Pengadaan aset, Penatausahaan aset dan Penghapusan aset lalu ditunjang dengan pengendalian aplikasi yang baik sehingga kesalahan dalam pembuatan Laporan Keuangan dan Laporan aset
\end{abstract}


dapat diminimalisir, pada akhirnya akan menciptakan Laporan Keuangan Pemerintah Daerah yang andal, transparan dan akuntabel.

Kata Kunci: aplikasi sistem informasi manajemen daerah; pengelolaan keuangan daerah

\begin{abstract}
Good local government financial governance can be seen with the good published financial statement, which is relevant, understandable, can be tested, punctual, comparable and complete. To achieve that we need the right tools that is the competence human resources, a whole year of continuous monitoring and an application to govern the local government financial. Sistem Informasi Manajemen Daerah (SIMDA) is an application used by many local government, this application covers budgeting, which is the beginning of the local government financial governance, administration, which is the controlling the expense in a year and other output like reports for the financial statement such as ledger and part of financial statement like cash flow statement and balance sheet. The method in this paper is qualitative research method and case study approach. Subject in this research is called the source of information and the object in this research is Sistem Informasi Manajemen Daerah (SIMDA) Keuangan and SIMDA BMD. One source of information in this research is the user of the application. SIMDA Keuangan and SIMDA BMD is made to help local government create financial statement and asset statement through information technology as the media, with the automatical process in SIMDA Keuangan which started with planning that is Budget Work Plan and Budget Execution Document then in administration financial process which is started with Letter of Provision of Funds, Payment Order, Accountability Letter, Disbursement Order and ended in the Accounting process which is posting the journals that appear because of the administration process, in SIMDA BMD process that happen are asset planning, asset procurement, asset administration and asset deletion, with the support of good application control so that local government can reduce the mistake made in creating financial statement and asset statement, so finally, the local goverment can create the best financial statement that is reliable, transparant and accountable.
\end{abstract}

Keywords: regional management information system application; regional financial management

Received: 2021-10-20; Accepted: 2021-11-05; Published: 2021-11-20

\title{
Pendahuluan
}

Di era globalisasi seperti sekarang ini, komputer telah menjadi alat yang umum di pakai untuk melakukan pekerjaan sehari-hari seperti membuat presentasi, membuat laporan atau melakukan pendataan statistik, tak terkecuali juga dalam pembuatan laporan keuangan pada Pemerintah Daerah.

Laporan Keuangan Pemerintah Daerah (LKPD) adalah bentuk pertanggungjawaban pemerintah daerah atas pengelolaan sumber daya ekonomi yang 
digunakan oleh pemerintah selama satu periode. Laporan keuangan pemerintah daerah wajib mengikuti standar akuntansi pemerintahan sesuai peraturan pemerintah Nomor 71 tahun 2010 (Ariska, Masniadi, \& Rachman, 2019).

Pembuatan laporan keuangan baik di sektor publik maupun swasta, telah lazim dilakukan dengan menggunakan aplikasi komputer, pembuat software aplikasi untuk akuntansi dan laporan keuangan di Indonesia pun telah banyak dan berkembang sehingga perusahaan tinggal memilih software aplikasi yang paling compatible dan paling efektif baik dari segi penginputan maupun pengoperasian software tersebut untuk mereka untuk menghasilkan laporan keuangan.

Efektifitas pengelolaan melalui perencanaan, proses sampai dengan pelaporan data-data keuangan juga akan terwujud melalui aspek sumber daya manusia yang handal dan mengerti dengan apa yang akan dikerjakan dan digunakan, penerapan SIM butuh aspek SDM yang berkualitas guna mencapai efektifitas kinerja pelaporan anggaran di tiap OPD. Sistem informasi manajemen (SIM) akan memberikan manfaat yang besar bagi suatu entitas organisasi, dalam hal ini adalah unit OPD. Dengan SIM, tata pengelolaan data keuangan akan terkoordinasi dan tersistemisasi satu dengan yang lainnya, sehingga kecil kemungkinan untuk data bermasalah atau data error. Hal ini tentu akan mempermudah sistem pelaporan keuangan di birokrasi, utamanya sistem birokrasi di daerah (Yanto \& Afkir, 2020).

Kajian ini mengkaji salah satu software aplikasi untuk standar akuntansi dan laporan keuangan pada pemerintah daerah. Software aplikasi diperuntukkan untuk kebutuhan pemerintah daerah juga telah banyak diperkenalkan, namun pada studi kali ini akan dibahas mengenai aplikasi Sistem Informasi Manajemen Daerah (SIMDA) yang dibuat oleh Badan Pengawasan Keuangan dan Pembangunan (BPKP). Hal ini relevan dengan bidang akuntansi karena aplikasi Simda Informasi Manajemen Daerah ini merupakan aplikasi yang digunakan untuk penyusunan laporan keuangan yang merupakan hasil akhir dari Pengelolaan Keuangan.

Menurut (BPKP, 2011) dalam modulnya Modul Bimbingan Teknis Pedoman Pengoperasian Simda Keuangan, pengoperasian SIMDA Keuangan dan SIMDA BMD yaitu melalui menu-menu yang terbagi sebagai berikut:

1. Perencanaan yaitu dengan dibuatnya Rencana Kerja Anggaran (RKA) dan Dokumen Pelaksanaan Anggaran,

2. Penatausahaan Keuangan yang ditandai dengan dibuatnya Surat Penyediaan Dana (SPD), Surat Permintaan Pembayaran (SPP), Surat Perintah Membayar (SPM), Surat Pertanggungjawaban (SPJ) serta Surat Perintah Pencairan Dana (SP2D), dan

3. Akuntansi dengan melakukan posting terhadap jurnal-jurnal yang timbul karena proses penatausahaan.

Sedangkan pada SIMDA BMD proses yang ada yaitu sebagai berikut:

1. Perencanaan aset,

2. Pengadaan aset,

3. Penatausahaan aset dan 


\section{Penghapusan aset.}

Menurut (Watulingas \& Tangkuman, 2018) manfaat aplikasi SIMDA yaitu efisiensi untuk biaya perjalanan dinas, karena penginputan dapat dilakukan kapan saja dimana saja secara online. SIMDA (Sistem Informasi Manajemen Daerah) keuangan merupakan sistem yang digunakan untuk menyusun, memproses, mendapatkan, mengolah data dan menyimpan untuk menghasilkan informasi yang strategis.

Tujuan pengembangan Program Aplikasi SIMDA menurut (Hardjanto, 2019) adalah:

a) Menyediakan Database mengenai kondisi di daerah yang terpadu baik dari aspek keuangan, aset daerah, kepegawaian/aparatur daerah maupun pelayanan publik yang dapat digunakan untuk penilaian kinerja instansi pemerintah daerah.

b) Menghasilkan informasi yang komprehensif, tepat dan akurat kepada manajemen pemerintah daerah. Informasi ini dapat digunakan sebagai bahan untuk mengambil keputusan.

c) Mempersiapkan aparat daerah untuk mencapai tingkat penguasaan dan pendayagunaan teknologi informasi yang lebih baik.Memperkuat basis pemerintah daerah dalam melaksanakan otonomi daerah. Untuk perencanaan dan pelaporan kegiatan pada Organisasi Perangkat Daerah yang relevan, akurat, dan tepat BPKP mengembangkan program aplikasi berbasis dekstop dan webbased sebagai aplikasi keuangan yang digunakan dalam penyusunan rencana kerja dan anggaran pada pemerintah daerah. Aplikasi SIMDA digunakan pada organisasi pemerintah daerah secara terintegrasi satu dengan yang lain.

SIMDA yang nanti akan dijelaskan lebih lanjut merupakan produk BPKP yang diciptakan guna memfasilitasi Pemerintah Daerah untuk menciptakan output berupa laporan keuangan yang efisien, efektif dan akuntabel. SIMDA ini dibagi menjadi empat jenis antara lain SIMDA Keuangan, SIMDA Barang Milik Daerah (BMD), SIMDA Gaji dan SIMDA Pendapatan dan telah diimplementasikan di banyak pemerintah daerah. Pada Penelitian ini akan difokuskan kepada SIMDA Keuangan dan SIMDA BMD dimana kedua aplikasi tersebut adalah aplikasi utama dalam pembuatan Laporan Keuangan Pemda.

Namun aplikasi yang bagus saja tidaklah cukup, diperlukan juga pengendalian aplikasi agar input dan output yang masuk dan keluar dari aplikasi tidaklah Garbage In Garbage Out. Dalam pengendalian aplikasi dibutuhkan SDM yang berwenang dibidangnya agar dapat meminimalisir kesalahan-kesalahan dalam penginputan.

Menurut Penelitian (Polii \& Pontoh, 2018), unsur pengendalian aplikasi antara lain:

a) Pengendalian Batasan, yang fungsinya menjaga agar data yang diinput di aplikasi telah sesuai dengan aturan atau prosedur yang ditetapkan,

Diperlukan untuk membatasi siapa saja pengguna (user) yang dapat dipercaya untuk menggunakan aplikasi tersebut.

b) Pengendalian Masukan, 
Data yang akan diinput ke aplikasi harus dipastikan sudah benar sesuai dengan aturan yang berlaku untuk mendeteksi sekaligus mencegah jika terdapat kesalahan ketika pemasukan data. Pengelolaan data keuangan menggunakan SIMDA Keuangan memiliki prosedur yang sudah ditetapkan, mulai dari pengguna (user) yang dapat menggunakannya sampai dengan data apa saja yang diperlukan oleh aplikasi dalam proses pembuatan suatu dokumen.

c) Pengendalian Proses

Untuk memastikan pengeloaan data dalam suatu aplikasi telah dilakukan secara benar. Pengendalian ini sebenarnya sudah dilaksanakan dalam pemrogaman aplikasi SIMDA Keuangan dengan adanya program untuk melakukan penolakan otomatis ketika data yang diinput tidak sesuai dengan yang diminta oleh aplikasi dan peringatan untuk mengoreksi bila ada kesalahan ketika penginputan, sehingga ketepatan data dapat terjaga selama proses pengolahan sampai dengan output dihasilkan. Pengendalian proses juga ditunjang oleh koordinasi yang dilakukan.

Dari latar belakang tersebut, maka penulis akan meneliti mengenai pengelolaan keuangan dan aset daerah dengan menggunakan SIMDA Keuangan dan SIMDA BMD.

\section{Metode Penelitian}

Penelitian kualitatif adalah metode yang digunakan oleh penulis dengan menggunakan studi terhadap kasus. Menurut (Sugiyono, 2010) Metode penelitian kualitatif adalah metode yang digunakan untuk meneliti pada kondisi aplikasi yang alamiah dimana peneliti adalah sebagai instrument kunci dalam pengumpulan data.

Narasuber merupakan subjek dalam penelitian ini, dengan objeknya Sistem Informasi Manajemen Daerah (SIMDA) Keuangan dan BMD. Ada satu narasumber dalam penelitian ini yaitu unsur pemakai aplikasi.

Penelitian ini dilakukan dengan analisis data kualitatif dan dilaksanakan pada bulan November 2021. Data yang dikumpulkan akan menghasilkan data primer yaitu Data aplikasi SIMDA Keuangan dan SIMDA BMD serta data sekunder yaitu data dari penelitian terdahulu.

Berikut penelitian terdahulu sebagai data sekunder yang terdapat dalam penelitian ini:

Tabel 1

Penelitian Terdahulu

\begin{tabular}{|c|c|c|}
\hline Penulis & Identitas Jurnal & Judul \\
\hline $\begin{array}{l}\text { (Ariska et al., } \\
2019)\end{array}$ & $\begin{array}{l}\text { Vol, Hal \& Tahun: } \\
\text { Jurnal Riset Kajian } \\
\text { Teknologi } \\
\text { Lingkungan } \\
\text { Vol. 2 Issue } \\
\text { 15-23 }\end{array}$ & $\begin{array}{lcr}\text { Penerapan } & \text { SIMDA } & \text { terhadaP } \\
\text { Kualitas } & \text { Laporan } & \text { Keuangan } \\
\text { SKPD } & \text { di } & \text { Kabupaten } \\
\text { SUMBAWA } & & \end{array}$ \\
\hline $\begin{array}{l}\text { (Yanto \& Afkir, } \\
2020)\end{array}$ & $\begin{array}{l}\text { Vol, Hal \& Tahun: } \\
\text { Indonesian Journal of }\end{array}$ & $\begin{array}{r}\text { PENERAPAN } \\
\text { INFORMASI }\end{array}$ \\
\hline
\end{tabular}




\begin{tabular}{|c|c|c|}
\hline Penulis & Identitas Jurnal & \\
\hline & $\begin{array}{l}\text { Strategic Management } \\
\text { Vol. } 3 \text { Issue } 12019 \\
\text { DOI: } \\
\text { https://doi.org/10.25134/i } \\
\text { jsm.v3i1.2819 }\end{array}$ & $\begin{array}{lr}\text { MANAJEMEN } & \text { KEUANGAN } \\
\text { DAERAH } & \text { (SIMDA } \\
\text { KEUANGAN) } & \end{array}$ \\
\hline (Watulingas & Vol, Hal \& Tahun: & IPTEKS APLIKASI \\
\hline Tangkuman, & $\begin{array}{l}\text { Jurnal Ipteks Akuntansi } \\
\text { bagi Masyarakat } \\
\text { Vol. } 2 \text { No .2, 2018, Hal : } \\
\text { 434-436 } \\
\text { DOI: } \\
\text { 10.32400/jiam.2.02.2018. } \\
21797\end{array}$ & $\begin{array}{lr}\text { INFORMASI } & \text { MANAJEMEN } \\
\text { DAERAH } & \text { (SIMDA) } \\
\text { KEUANGAN PADA } & \text { BADAN } \\
\text { PERENCANAAN } & \text { DAN } \\
\text { PEMBANGUNAN } & \text { DAERAH } \\
\text { PROVINSI } & \text { SULAWESI } \\
\text { UTARA } & \\
\end{array}$ \\
\hline (Har & $\begin{array}{l}\text { JURNAL TEKNIK } \\
\text { INFORMATIKA } \\
\text { Vol 12 No.1, 2019, Hal } \\
11-20 \\
\text { DOI: } \\
\text { https://doi.org/10.15408/j } \\
\text { ti.v12i1.6263 }\end{array}$ & \begin{tabular}{lr} 
IMPLEMENTASI & SISTEM \\
INFORMASI & MANAJEMEN \\
DAERAH & (SIMDA) \\
KEUANGAN & BERBASIS \\
AKRUAL PADA DINAS & PERTANIAN DAN PANGAN \\
\multicolumn{2}{l}{ KOTA MAGELANG }
\end{tabular} \\
\hline $\begin{array}{l}\text { (Polii \& Pontoh, } \\
2018)\end{array}$ & $\begin{array}{l}\text { Jurnal Ipteks Akuntansi } \\
\text { bagi Masyarakat } \\
\text { Vol. } 2 \text { No. 2, 2018, Hal: } \\
\text { 246-250 } \\
\text { DOI: } \\
\text { https://doi.org/10.32400/j } \\
\text { iam.2.02.2018.21743 }\end{array}$ & $\begin{array}{lr}\text { IPTEKS } & \text { PENGENDALIAN } \\
\text { INTERN SIMDA KEUANGAN } \\
\text { DALAM } & \text { PENGELOLAAN } \\
\text { DATA KEUANGAN PADA } \\
\text { BADAN } & \text { PERENCANAAN } \\
\text { DAN } & \text { PEMBANGUNAN } \\
\text { DAERAH } & \text { (BAPPEDA) } \\
\text { PROVINSI } & \text { SULAWESI } \\
\text { UTARA } & \\
\end{array}$ \\
\hline $\begin{array}{l}\text { (Ananda \& Sari, } \\
\text { 2020) }\end{array}$ & $\begin{array}{l}\text { Jurnal Pundi } \\
\text { Vol. 4, No.02, 2020, Hal: } \\
241-250 \\
\text { DOI:10.31575/jp.v4i2.21 } \\
4\end{array}$ & 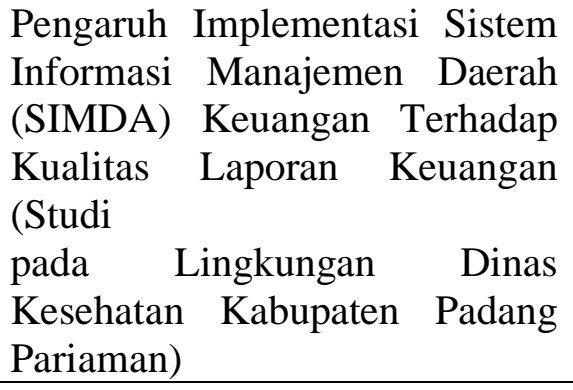 \\
\hline $\begin{array}{l}\text { (Darea \& Elim, } \\
\text { 2015) }\end{array}$ & $\begin{array}{l}\text { Jurnal EMBA } \\
\text { Vol. } 3 \text { No.2 2015 } \\
\text { https://doi.org/10.35794/ } \\
\text { emba.3.2.2015.8361 }\end{array}$ & $\begin{array}{lr}\text { EVALUASI } & \text { PENERAPAN } \\
\text { SISTEM } & \text { INFORMASI } \\
\text { MANAJEMEN } & \text { DAERAH } \\
\text { (SIMDA) KEUANGAN PADA } \\
\text { DPPKA } & \text { KABUPATEN } \\
\text { KEPULAUAN SANGIHE. }\end{array}$ \\
\hline $\begin{array}{l}\text { (Sultan \& Fatimah, } \\
\text { 2016) }\end{array}$ & $\begin{array}{l}\text { Jurnal } \quad \text { Komunikasi } \\
\text { KAREBA } \\
\text { Vol. 5 No.1 } 2016 \text { Hal } \\
118-129\end{array}$ & $\begin{array}{lr}\text { EVALUASI } & \text { SISTEM } \\
\text { INFORMASI MANAJEMAN } \\
\text { BARANG MILIK } \\
\text { (SIMDA-BMD) } & \text { DALAM } \\
\end{array}$ \\
\hline
\end{tabular}




\begin{tabular}{|c|c|c|}
\hline Penulis & Identitas Jurnal & Judul \\
\hline & https://doi.org/10.31947/ & MENDUKUNG \\
\hline & kjik.v5i1.1888 & INVENTARISASI \\
\hline & & DAERAH DI KABUPATEN \\
\hline & & MAJENE \\
\hline \multirow{7}{*}{$\begin{array}{l}\text { (Utami } \quad \& \quad \text { Sari, } \\
\text { 2017) }\end{array}$} & \multirow{7}{*}{$\begin{array}{l}\text { Jurnal MONEX } \\
\text { Vol } 6 \text { No.1 } 2017 \text { Hal } \\
\text { 224-229 } \\
\text { http://dx.doi.org/10.3059 } \\
\text { 1/monex.v6i1.454 }\end{array}$} & EFEKTIVITAS \\
\hline & & \multirow{6}{*}{ 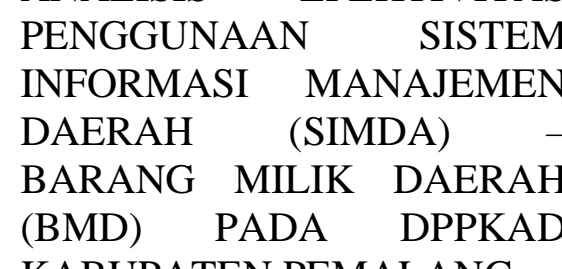 } \\
\hline & & \\
\hline & & \\
\hline & & \\
\hline & & \\
\hline & & \\
\hline \multirow[t]{11}{*}{ (Nugraha, 2013) } & \multirow{11}{*}{$\begin{array}{l}\text { Jurnal Akuntansi Akrual, } \\
\text { Vol 2, No.1. } 2013 \text { Hal } \\
\text { 25-33 }\end{array}$} & ANALISIS $\quad$ PENERAPAN \\
\hline & & \multirow{9}{*}{$\begin{array}{r}\text { PENERAPAN } \\
\text { INFORMASI } \\
\text { KEUANGAN } \\
\text { (SIMDA } \\
\text { DALAM } \\
\text { DATA } \\
\text { PADA } \\
\text { PEMERINTAH } \\
\text { UDI KASUS } \\
\text { KESEHATAN } \\
\text { JGANJUK) }\end{array}$} \\
\hline & & \\
\hline & & \\
\hline & & \\
\hline & & \\
\hline & & \\
\hline & & \\
\hline & & \\
\hline & & \\
\hline & & KABUPATEN NGANJUK) \\
\hline \multirow{9}{*}{$\begin{array}{l}\text { (Inayah, Hakiki, \& } \\
\text { Relasari, 2016) }\end{array}$} & \multirow{9}{*}{$\begin{array}{l}\text { Akuntabilitas:Jurnal } \\
\text { Penelitian dan } \\
\text { Pengembangan } \\
\text { Akuntansi } \\
\text { Vol.10 No.2. } 2016 \text { Hal } \\
\text { 167-176. } \\
\text { DOI: } \\
\text { https://doi.org/10.29259/j } \\
\text { a.v10i2.8892 }\end{array}$} & ANALISIS \\
\hline & & MANAJEMEN \\
\hline & & DAERAH \\
\hline & & KEUANGAN PADA DINAS \\
\hline & & $\begin{array}{l}\text { PENDAPATAN, } \\
\text { PENGELOLAAN }\end{array}$ \\
\hline & & KEUANGAN \\
\hline & & DAERAH \\
\hline & & KABUPATEN \\
\hline & & LAHAT \\
\hline
\end{tabular}

\section{Hasil dan Pembahasan}

\section{A. Aplikasi SIMDA}

\section{Program Aplikasi SIMDA Keuangan}

Aplikasi ini dipakai oleh Pemerintah Daerah sebagai sarana untuk mengelola keuangan daerah dengan ruang lingkup: Pengelolaan Anggaran, Pengelolaan Penatausahaan, Pelaksanaan akuntansi dan pelaporannya dengan Output:

a) Penganggaran

- Rencana Kerja Anggaran (RKA),

- RAPBD dan Rancangan Penjabaran APBD,

- APBD dan Penjabaran APBD beserta perubahannya, dan $\backslash$

- Dokumen Pelaksanaan Anggaran (DPA). 
Pengendalian intern ditandai dengan adanya pencocokan data antara pembuat DPA sampai akhirnya di buat Surat Penyediaan Dana (SPD) yang nantinya akan digunakan pada saat melakukan Penatausahaan.

b) Penatausahaan, meliputi:

- Surat Penyediaan Dana (SPD),

- Surat Permintaan Pembayaran (SPP),

- Surat Perintah Membayar (SPM),

- SPJ,

- Surat Perintah Pencairan Dana (SP2D),

- Surat Tanda Setoran (STS), beserta register-register, dan formulir-formulir pengendalian anggaran lainya.

Pengendalian intern ditandai ketika akan membuat SPM dimana dibutuhkan verifikasi pada SPP-nya, ketika verifikasi tidak dilakukan maka SPM tidak dapat dibuat. Begitu pula dengan SP2D, SP2D baru dapat dibuat ketika SPM di-Final-kan.

c) Akuntansi dan Pelaporan, meliputi:

- Proses penjurnalan,

- Buku Besar,

- Buku Pembantu,

- Laporan Realisasi Anggaran,

- Laporan Arus Kas,

- Neraca, dan

- Perda Pertanggungjawaban dan Penjabarannya.

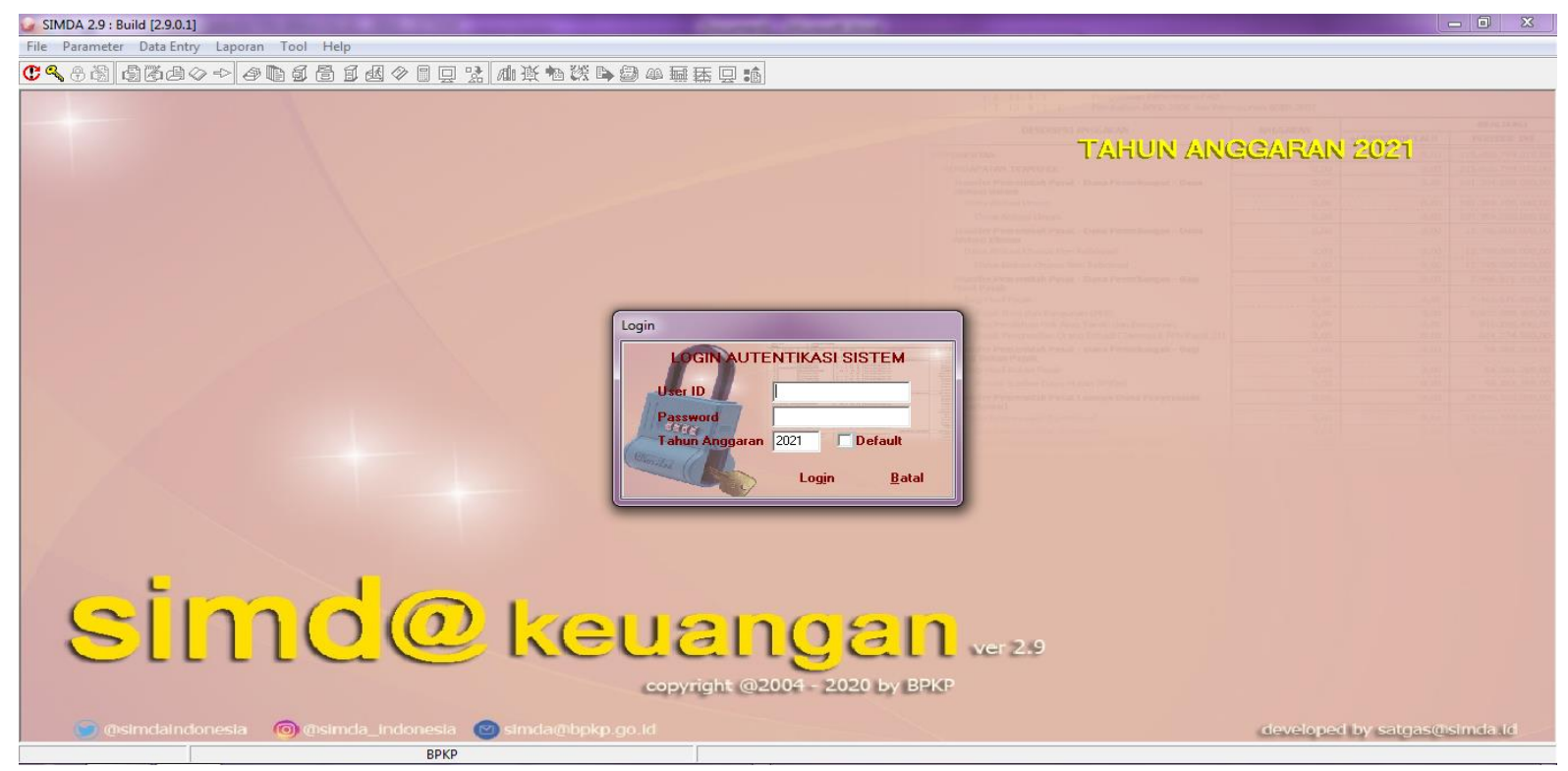

\section{Gambar 1}

Tampilan Login SIMDA Keuangan

Laporan-laporan diatas baru dapat dibuat ketika Jurnal yang dihasilkan dari proses penatausahaan selesai di-posting. Sehingga dibutuhkan komunikasi sebagai 
pengendalian intern antara bagian yang melakukan bagian penatausahaan dan bagian akuntansi.

\section{Program Aplikasi SIMDA BMD}

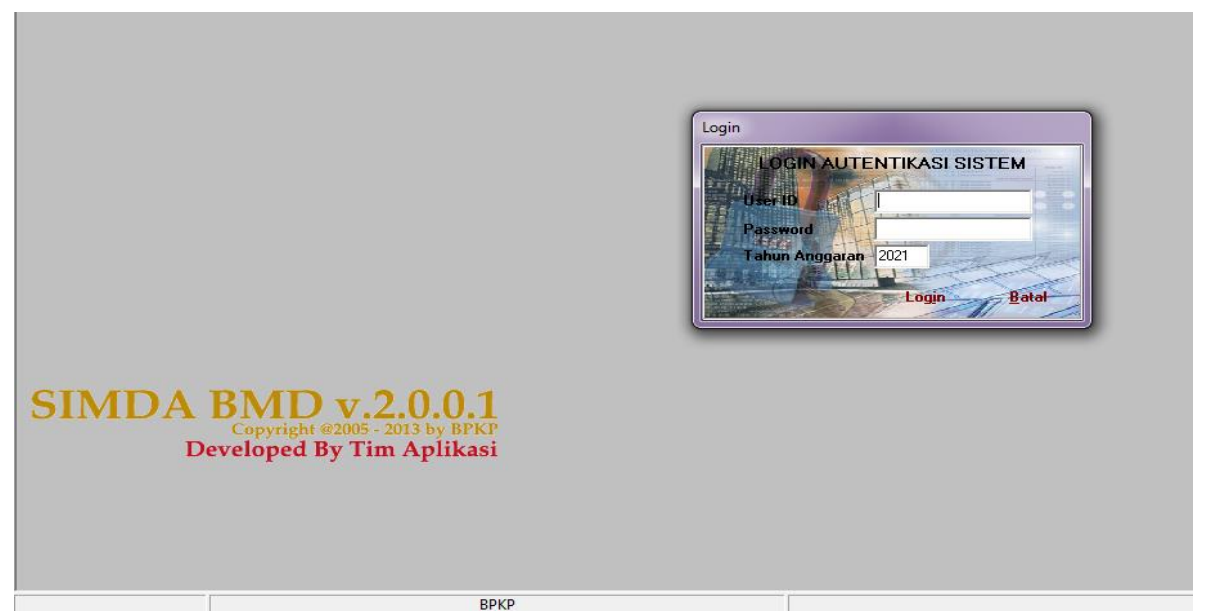

Gambar 2

Tampilan Login SIMDA BMD

Aplikasi SIMDA BMD berfokus pada pengelolaan barang/aset daerah meliputi perencanaan aset, pengadaan aset, penatausahaan aset, penghapusan aset dan proses akuntansinya, dengan Output:

a) Perencanaan, antara lain:

- Daftar Kebutuhan Barang dan Pemeliharaan,

- Daftar Rencana Pengadaan Barang Daerah, dan

- Daftar Rencana Pemeliharaan Barang Daerah.

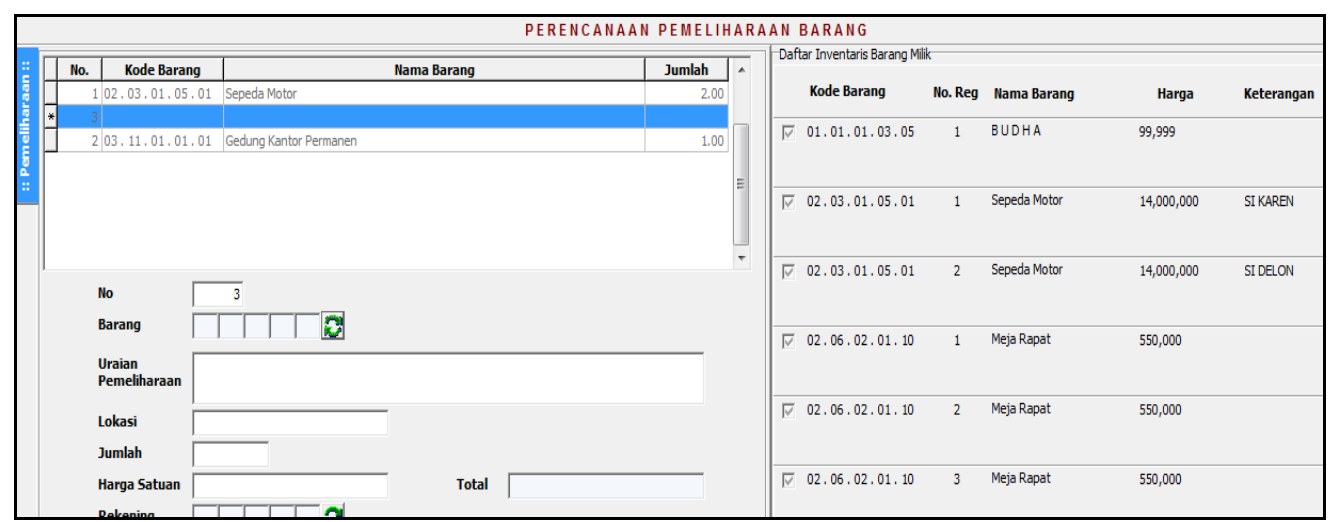

Gambar 3

Tata cara input Perencanaan

b) Pengadaan, meliputi:

- Daftar Hasil Pengadaan,

- Daftar Hasil Pemeliharan Barang, dan

- Daftar Kontrak Pengadaan. 


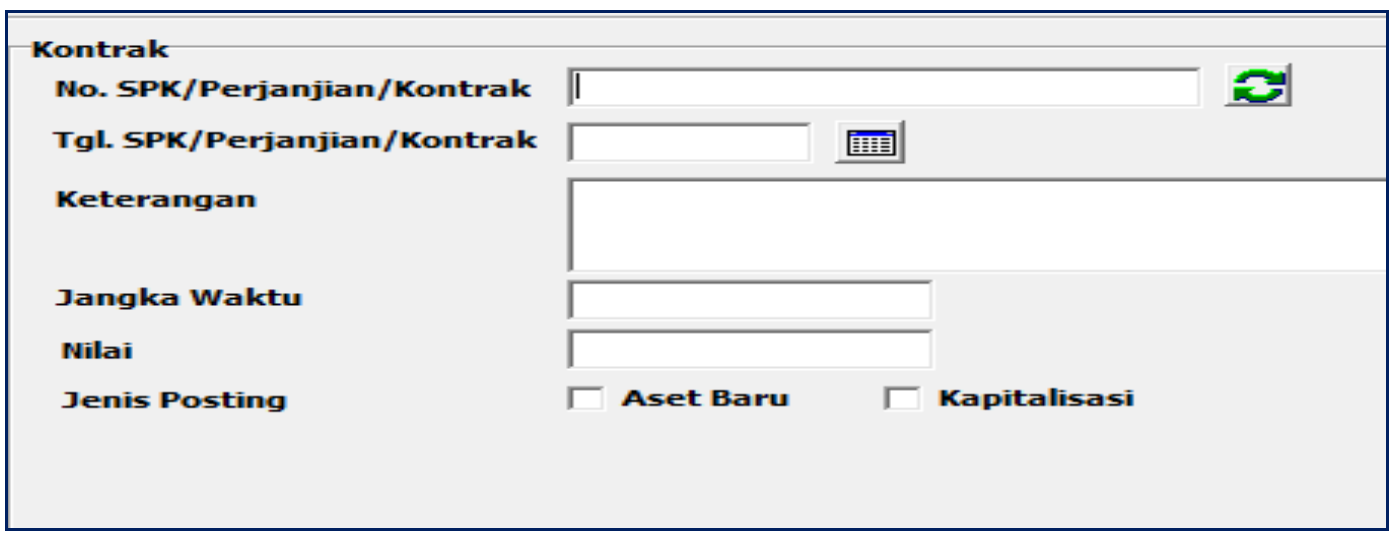

\section{Gambar 4}

Tata cara input pengadaan

Salah satu pengendalian pada tahapan pengadaan adalah pemilihan Nomor dan Tanggal Kontrak yang dapat langsung dipilih apabila Kontrak telah diinput sebelumnya pada menu dan aplikasi yang berbeda.

c) Penatausahaan, meliputi:

- Kartu Inventaris Barang (KIB),

- Kartu Barang,

- Kartu Inventaris ruangan (KIR),

- Buku Inventaris ,

- Daftar Mutasi Barang Daerah, dan

- Rekap Hasil Sensus, serta Label Barang.

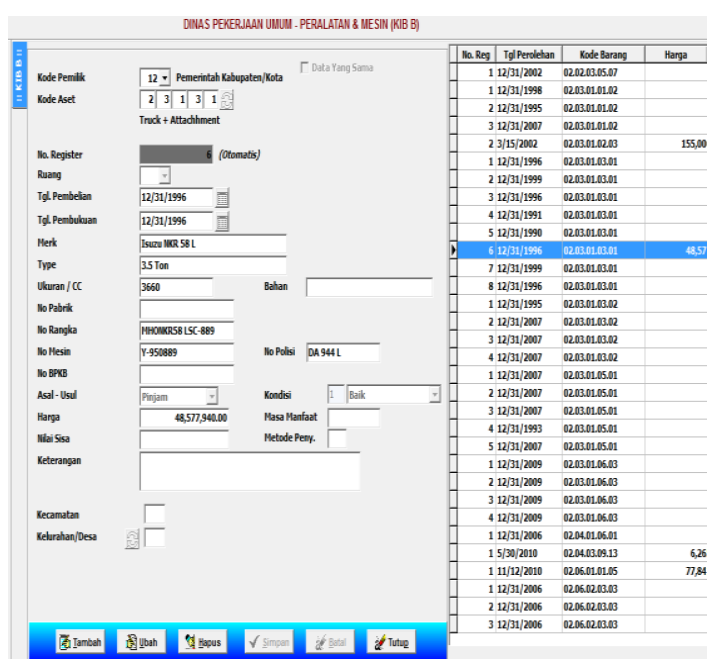

Gambar 5

Tata cara input penatausahaan

d) Penghapusan, meliputi:

- SK Penghapusan,

- Lampiran SK Penghapusan, dan

- Daftar Barang yang dihapus. 


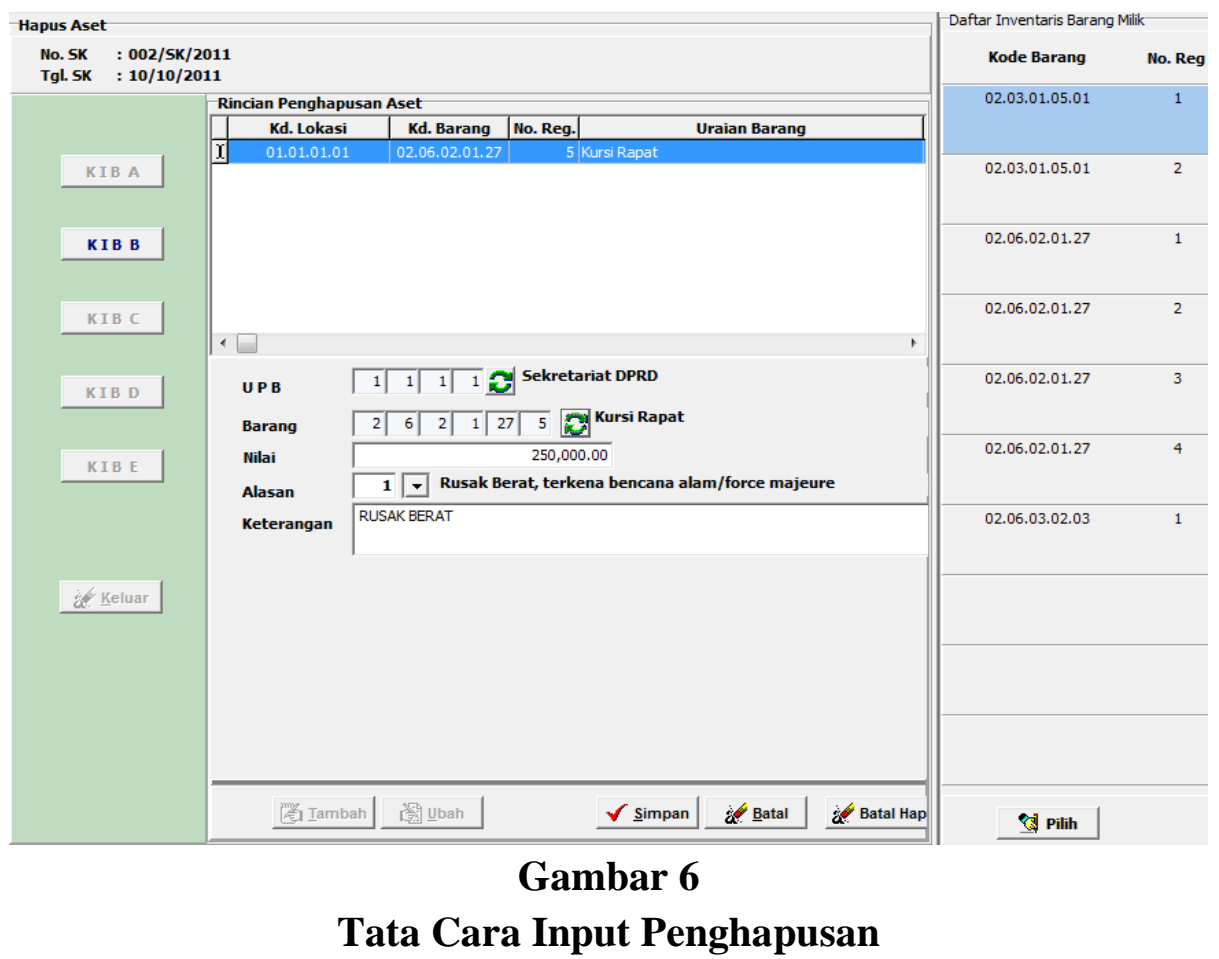

Penghapusan baru dapat diinput ketika telah muncul SK Penghapusan yang dikeluarkan oleh pihak yang berwenang, sehingga dibutuhkan pengendalian berupa konfirmasi antara barang yang tercantum pada SK Penghapusan dengan aset yang dihapus pada aplikasi.

e) Akuntansi pada aset, meliputi:

- Barang Intracomptable,

- Barang extracomptable,

- Lampiran Neraca,

- Daftar Penyusutan Aset Tetap,

- dan Daftar Aset Lainnya, serta Rekapitulasi Barang Per SKPD.

Agar didapatkan data akurat untuk diinput pada aplikasi dibutuhkan pengendalian berupa rekonsiliasi data yaitu proses pencocokan data antara Perangkat Daerah yang bertugas melakukan pencatatan aset dan Satuan Kerja Perangkat Daerah yang melakukan pengadaan aset.

\section{B. Alur Penginputan SIMDA Keuangan \\ 1. Penganggaran}

Hal Pertama yang menjadi dasar dari semua Pengeluaran dan Pendapatan dari pemerintah daerah adalah Penganggaran karena apabila tidak ada penganggaran yang dalam hal ini di tandai dengan terbitnya Dokumen Pelaksaan Anggaran, maka pengeluaran pemerintah daerah tidak akan ada dasar pengeluarannya. Dalam SIMDA, Penganggaran ditandai dengan diisinya RKA, Rencana Kerja (Renja) serta Rencana Strategis (Renstra). 
Dalam Pengisian RKA, terlebih dahulu diisi Program Kegiatan untuk masingmasing SKPD yang bersangkutan, setelah Program Kegiatan diisi penginputan beralih ke Renstra yang berisi:

- Data umum,

- Alamat,

- Nama dan jabatan pimpinan,

- Data jabatan unit organisasi,

- Tupoksi SKPD

- Visi, Misi, Tujuan dan Sasaran, dan

- Program, Kegiatan beserta Indikator

Dalam masing-masing belanja SKPD terdapat batas penggunaan dana yang dinamakan pagu, pagu ini diisi didalam Renja yang nantinya belanja dari perangkat daerah tidak boleh lebih dari pagu, Setelah pagu masing-masing belanja diisi, maka RKA yang merupakan inti dari penggangaran dapat diisi.

RKA adalah dokumen yang memuat perencanaan dan penganggaran dari perangkat daerah yang akan digunakan sebagai dasar dalam penyusunan APBD, RKA antara lain memuat:

- Rencana pendapatan,

- Rencana belanja untuk masing-masing program dan kegiatan, serta

- Rencana pembiayaan

Dokumen tersebut digunakan untuk tahun yang direncanakan, penginputan dalam SIMDA dilakukan sampai dengan rincian obyek baik untuk pendapatan, belanja dan pembiayaan, dengan keterangan nilai anggaran pada tahun sebelumnya serta prakiraan anggaran maju untuk tahun berikutnya, jadi jelas disini bahwa RKA diinput untuk masing-masing belanja dengan memperhatikan detail belanja dan nilai satuan. Keuntungan dalam memakai aplikasi adalah setelah penginputan angka masing-masing kegiatan telah otomatis terakumulasi serta tidak mungkin melebihi pagu anggaran yang telah ditetapkan. Setelah Penginputan RKA selesai, maka DPA dapat dicetak pada menu laporan di aplikasi yang nantinya akan digunakan untuk penerbitan SPD.

Surat Penyediaan Dana (SPD) pada SIMDA digunakan sebagai dasar penerbitan SPP, apabila SPD belum diinput atau dana pada SPD tidak mencukupi, maka SPP tidak dapat dibuat. Didalam aplikasi, SPD adalah hal pertama yang diinput setelah keluarnya DPA. SPD merupakan batas belanja suatu kegiatan jadi apabila melebihi batas belanja tersebut maka aplikasi akan otomatis menolak untuk diinput. 


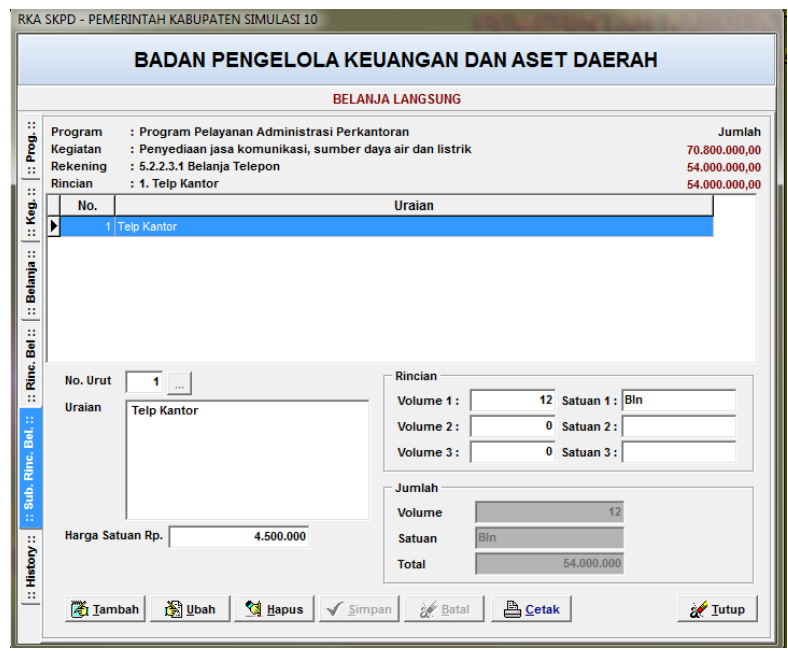

Gambar 7

Cara input RKA

\section{Penatausahaan}

Setelah Penganggaran selesai diinput maka tongkat estafet di berikan pada bagian penatausahaan, ini merupakan bagian paling panjang dalam bagian pengelolaan keuangan daerah karena penatausahaan ini secara berkesinambungan dilakukan selama setahun penuh.

Dimulainya penatausahaan ditandai dengan adanya Surat Permintaan Pembayaran (SPP) sebagai awal untuk meminta dana yang digunakan membiayai kegiatan. Menurut Permendagri 21 Tahun 2011, SPP adalah dokumen yang diterbitkan oleh pejabat yang bertanggung jawab atas pelaksanaan kegiatan atau bendahara pengeluaran yang digunakan untuk mengajukan permintaan pembayaran.

SPP dibagi menjadi 4, yaitu:

$>$ SPP-Uang Persediaan (UP) adalah dokumen bendahara pengeluaran ketika akan meminta uang muka kerja.

$>$ SPP-Ganti Uang Persediaan (GU) adalah dokumen bendahara pengeluaran Ketika akan mengajukan permintaan penggantian uang persediaan (UP).

> SPP-Tambahan Uang Persediaan (TU) adalah dokumen bendahara pengeluaran ketika akan meminta tambahan uang persediaan (UP), SPP-TU digunakan untuk melaksanakan kegiatan SKPD yang mendesak.

$>$ SPP Langsung (LS) adalah dokumen bendahara pengeluaran ketika akan meminta pembayaran yang langsung, baik kepada pihak ketiga dan pembayaran gaji.

Dalam penginputan di aplikasi harus jelas terlebih dahulu apakah kita akan menginput SPP-UP, SPP-GU, SPP-TU atau SPP-LS karena output yang dikeluarkan oleh aplikasi akan berbeda. SPP diinput secara rinci dengan memperhatikan nomor rekening yang ada serta dibatasi dengan adanya SPD. Setelah SPP selesai diinput lalu diverifikasi dan hasilnya menjadi bahan untuk membuat SPM. 


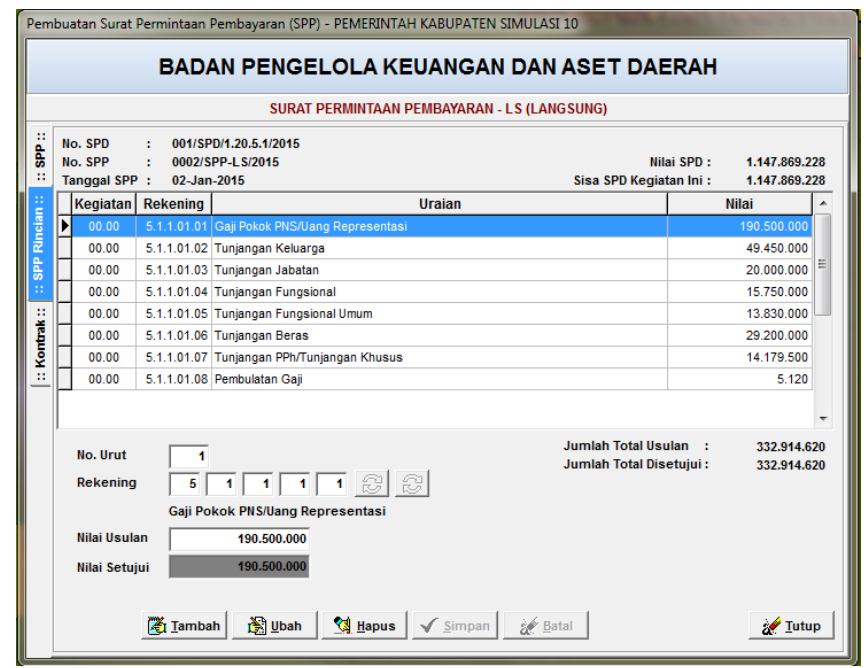

\section{Gambar 8 \\ Tata cara input SPP}

Menurut Permendagri 21 Tahun 2011, Surat Perintah Membayar (SPM) adalah dokumen yang digunakan/diterbitkan oleh pengguna anggaran/kuasa pengguna anggaran untuk penerbitan SP2D atas beban pengeluaran DPA-SKPD, di SIMDA penginputan SPM dilakukan setelah SPP selesai diinput, nilai yang ada di SPM merupakan nilai yang mengacu dari SPP, yang harus diperhatikan pada saat penginputan adalah tanggal SPM tidak boleh lebih rendah dari tanggal SPP atau sistem akan menolak nantinya. Di SPM ini juga nantinya akan diinput pajak dan potongan lainnya. Setelah SPM selesai diinput maka SKPD akan menyerahkan data berupa dokumen dan juga hasil ekspor data SPP dan SPM kepada dinas pengelola keuangan daerah dimana dinas tersebut akan membuat Surat Perintah Pencairan Dana (SP2D).

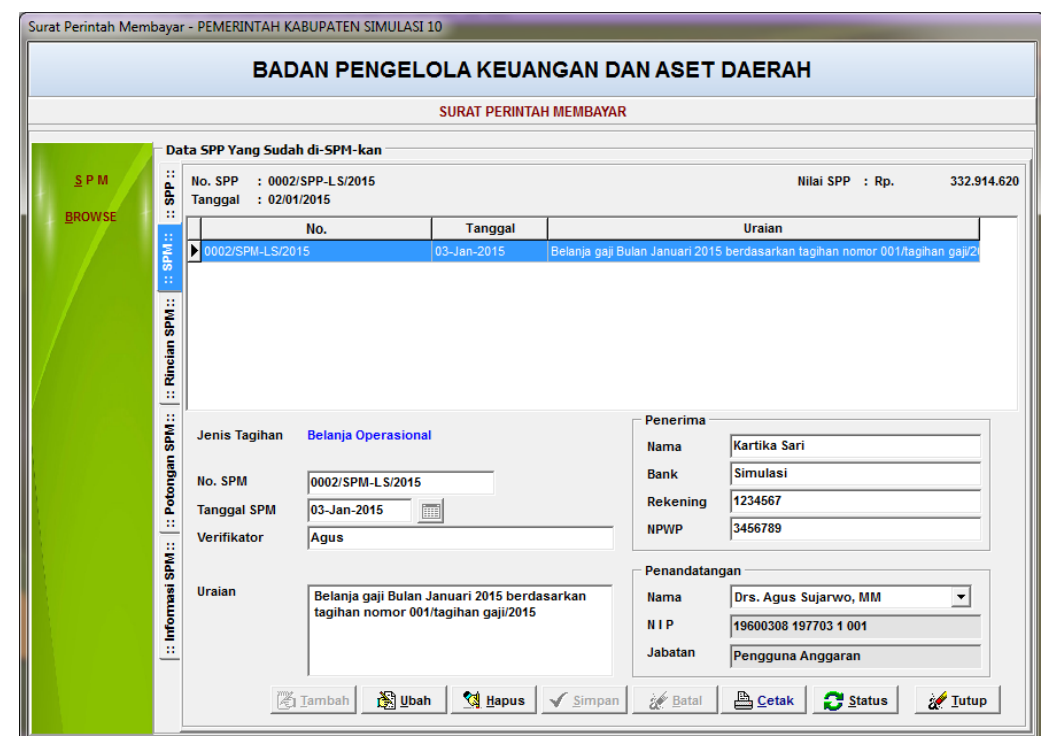

Gambar 9

Tata cara input SPM 
Menurut Permendagri 21 tahun 2011, SP2D merupakan dokumen yang digunakan sebagai dasar pencairan dana yang diterbitkan oleh BUD berdasarkan SPM, penginputan SP2D dilakukan oleh dinas pengelolaan keuangan daerah berdasarkan hasil impor data SPP dan SPM dari SKPD, penginputan SP2D terbilang cukup sederhana karena nilai rincian kegiatan tidak usah diinput kembali, sehingga yang diinput cukup nomor dan tanggal SP2D saja, untuk mendukung kesesuaian data antara dinas pengelolaan keuangan daerah dan SKPD maka diharapkan setelah selesai menerbitkan SP2D, dinas tersebut harus menyerahkan data ekspor SP2D untuk nantinya diimpor oleh SKPD di server masing-masing.

Untuk SP2D UP, apabila telah diterbitkan maka diwajibkan untuk membuat Surat Pertanggungjawaban (SPJ) GU di aplikasi dengan mengisi nomor, tanggal dan nilai yang disetujui untuk SPJ GU tersebut yang nantinya akan digunakan untuk membuat SPP GU. Untuk SP2D TU, apabila telah di terbitkan maka harus membuat SPJ TU yang nantinya digunakan untuk mengisi SPP-Nihil.

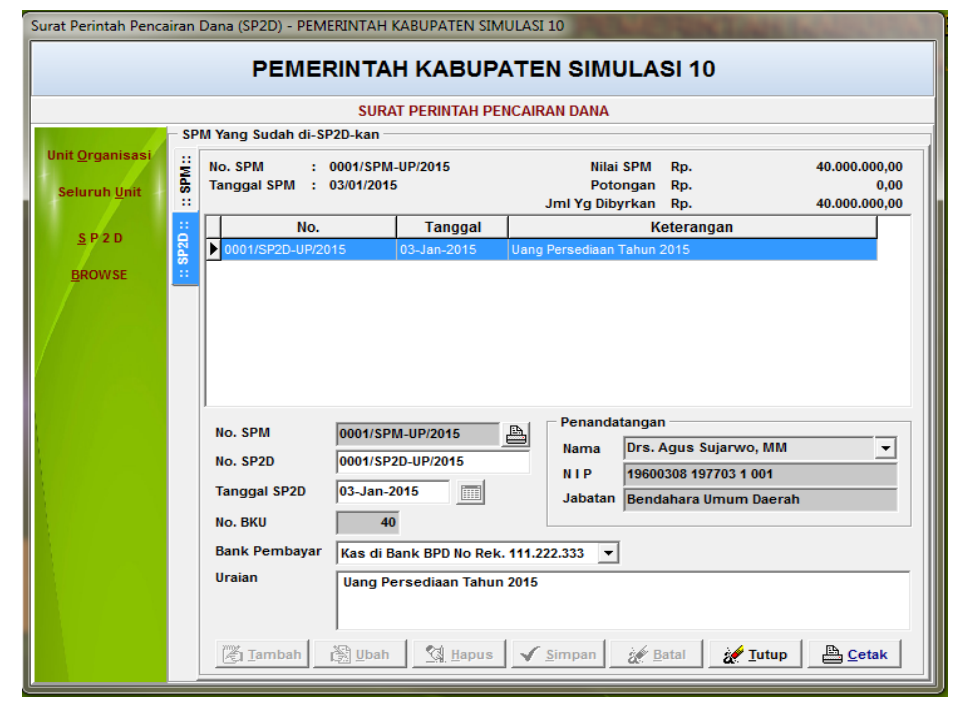

\section{Gambar 10}

Tata cara input SP2D

\section{Pelaporan}

Seperti yang dijelaskan diawal bahwa dalam program aplikasi SIMDA Keuangan ini output yang akan dihasilkan yaitu :

- Buku Besar,

- Buku Pembantu,

- Neraca

- Laporan Realisasi Anggaran,

- Laporan Arus Kas, dan

- Perda Pertanggungjawaban dan Penjabarannya,

namun sebelum dapat dihasilkan laporan tersebut ada beberapa hal yang perlu diperhatikan, antara lain :

a) Pendapatan 
Aplikasi SIMDA Keuangan bukanlah aplikasi pendapatan, namun untuk mendapat data laporan keuangan yang komprehensif maka diharapkan pendapatan juga di input. Penginputan pendapatan di SIMDA Keuangan dibagi menjadi Bukti Penerimaan dan Surat Tanda Setoran (STS) dimana Bukti Penerimaan diisi berdasarkan setoran oleh wajib pajak dengan mengisi nomor, tanggal, nilai serta nomor rekening pendapatan yang ada di aplikasi dan STS diisi berdasarkan Tanda Bukti Penerimaan yang telah dibuat sebelumnya, STS merupakan perwujudan dari bukti setor ke Bank yang telah ditunjuk oleh pemerintah daerah.

\section{b) Jurnal}

Pada menu jurnal di aplikasi SIMDA digunakan untuk melakukan penyesuaian ataupun koreksi. Menu koreksi pada SIMDA Keuangan digunakan pada proses akuntansi sebagai sarana agar pos-pos dalam laporan keuangan sesuai dengan yang keadaan seharusnya. Koreksi ini dilakukan sepanjang tahun.

Pada akhir tahun juga dilakukan penyesuaian sebagai sarana pembetulan secara akuntansi, agar pos-pos di laporan keuangan menunjukkan kondisi yang sebenarnya. Penyesuaian dilakukan dengan cara menginput jurnal penyesuaian, antara lain : Jurnal Penyesuaian pada saldo kas, Jurnal Penyesuaian pada persediaan, Jurnal Penyesuaian pada aktiva dalam pengerjaan, piutang serta utang.

c) Saldo awal

Saldo awal digunakan agar laporan keuangan yang tampil di laporan menyajikan laporan yang komparatif, data yang diinput merupakan data dari laporan keuangan tahun lalu meliputi neraca, LRA dan LAK tahun sebelumnya.

Dengan menggunakan diagram alur, proses penginputan Simda Keuangan adalah sebagai berikut :

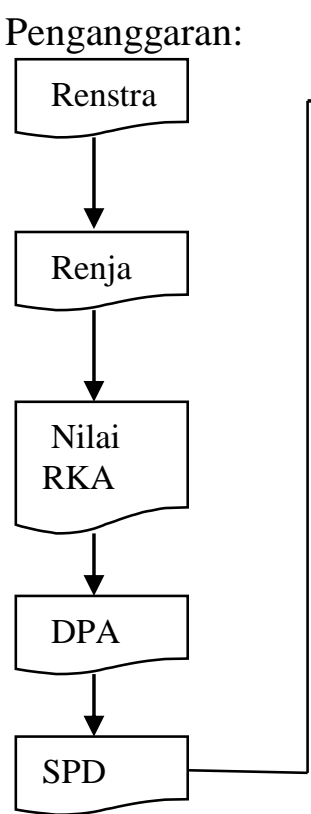

Belanja :

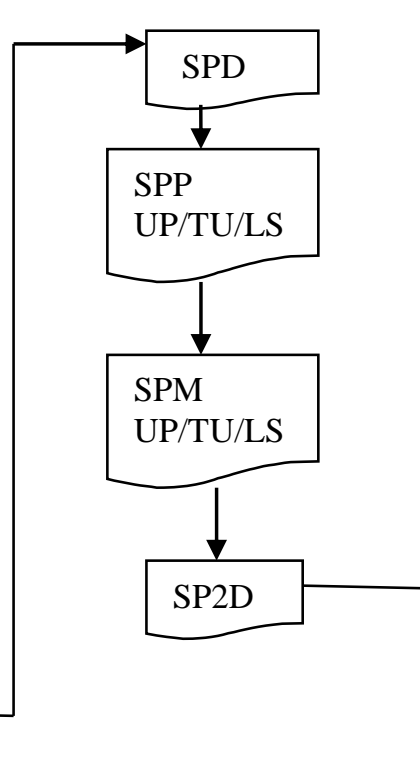

Pelaporan :

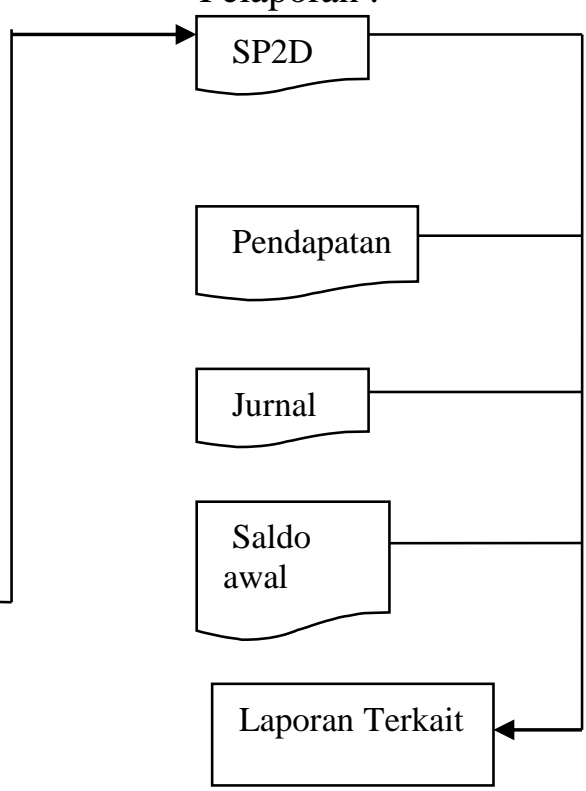

Gambar 11

Diagram Alur Proses Simda Keuangan 
Penggunaan Sistem Aplikasi SIMDA ini memiliki tujuan untuk mempermudah Pemerintah Daerah dalam melakukan pengelolaan keuangan daerah sehingga tercapainya pelaporan keuangan yang andal, transparan dan akuntabel karena dengan pengelolaan keuangan daerah yang dilakukan dengan menggunakan sistem maka risikorisiko kesalahan dalam proses penatausahaan baik dari Keuangan maupun Aset dapat diminimalisir karena adanya proses automatisasi sehingga kesalahan-kesalahan mendasar yang biasa dilakukan oleh manusia dapat dihindari.

Hal yang senada juga diungkapkan pada penelitian (Ananda \& Sari, 2020), bahwa SIMDA berpengaruh secara signifikan terhadap Kualitas Laporan Keuangan di Lingkungan Dinas Kesehatan Kabupaten Padang Pariaman, dimana responden berkeyakinan dengan menggunakan SIMDA dalam mengelola keuangan daerah dapat membantu meningkatkan kinerja dan individu yakin dalam menggunakan sistem akan membantu mencapai keuntungan dalam pekerjaan.

Sependapat dengan hal tersebut, penelitian oleh (Darea \& Elim, 2015), menyatakan bahwa dengan diterapkannya SIMDA Keuangan, proses penyajian laporan keuangan menjadi lebih cepat dan akurat. Hal ini berbeda dengan sebelum diterapkannya SIMDA Keuangan dimana penyajian laporan keuangannya membutuhkan proses yang lama dan menguras tenaga pembuat laporan keuangan. Perbandingannya adalah sebagai berikut:

Tabel 2

Perbandingan Penggunaan SIMDA

\begin{tabular}{|c|c|c|c|c|}
\hline $\begin{array}{l}\text { Sebelum } \\
\text { Keuangan }\end{array}$ & Menggunakan & SIMDA & $\begin{array}{l}\text { Setelah } \\
\text { Keuangan }\end{array}$ & Menggunakan \\
\hline
\end{tabular}

Waktu yang dibutuhkan lebih banyak Dengan menggunakan program dalam penyajian Laporan Keuangan komputerisasi yang bekerja secara otomatis sehingga memiliki kecepatan waktu dalam penyusunan laporan keuangan.

Tidak memiliki program rumus yang
baku sehingga sering terjadi kesalahan

Sumber tabel : Kesimpulan penelitian yang dilakukan oleh (Darea \& Elim, 2015)

Selain itu, penerapan SIMDA BMD pada Pemerintah Daerah juga sangat bermanfaat dalam pengelolaan aset didaerah tersebut, seperti yang diketahui bahwa aset adalah bagian yang sangat sering muncul pada temuan BPK, hal ini dikarenakan jumlah aset yang dikelola oleh Pemerintah Daerah sangat banyak dan seharusnya pengelolaan 
aset di Pemerintah Daerah membutuhkan perhatian khusus dari masing-masing Kepala Dinas pada Pemerintah Daerah sehingga diperlukan Tools agar pencatatan aset daerah dapat lebih akuntabel serta dapat menghasilkan informasi yang akurat, tepat dan akurat.

Sejalan dengan kajian (Sultan \& Fatimah, 2016) bahwa secara teknis, operasional dan ekonomis penggunaan SIMDA BMD di kabupaten Majene memberikan dampak yang cukup signifikan dari segi efektif, efisiensi secara waktu dan efisiensi secara dana. Informasi yang dihasilkan dari SIMDA BMD digunakan sebagai sumber informasi untuk dijadikan dasar pengambilan keputusan dalam rangka mencapai tujuan organisasi khususnya terkait pengelolaan BMD.

Kesimpulan yang senada juga diungkapkan dalam kajian (Utami \& Sari, 2017) bahwa efektifitas penggunaan SIMDA BMD pada DPPKAD Kabupaten Pemalang dapat dikatakan Efektif dengan persentase yang dihasilkan dari perhitungan sebesar 80\%. Dengan demikian usaha Pemerintah Daerah dalam memecahkan masalah pada pengelolaan Aset Daerah dengan menggunakan SIMDA BMD dapat dikatakan cukup berhasil,

Dalam hal pengendalian aplikasi, SIMDA telah menerapkan pengendalian aplikasi, (Nugraha, 2013) menyebutkan pengendalian-pengendalian yang digunakan pada SIMDA Keuangan diantaranya:

a) Pengendalian atas akses dan wewenang pemakai, dengan dipakainya akun serta password serta adanya pembagian kewenangan seperti administrator, supervisor dan operator.

b) Pengendalian keamanan dengan menggunakan uninterruptible power supply (UPS) sebagai pengaman daya.

c) Pengendalian pada fungsi menu untuk menjamin validitas masukan data.

d) Pengendalian pada aplikasi yang terdiri dari pengendalian masukan yang digunakan untuk mengetahui kesalahan dalam memasukkan data, pengendalian proses yang berfungsi untuk memastikan pemrosesan data telah dilakukan sesuai dengan prosedur dan

e) Pengendalian keluaran yang memiliki tujuan untuk menjamin output yang dihasilkan akurat dan benar.

Dalam Penelitian yang dilakukan oleh (Inayah et al., 2016), pengendalian intern yang telah dilakukan pada Dinas Pendapatan, Pengelolaan Keuangan dan Aset Daerah Kabupaten Lahat antara lain:

a) Pembangian kewenangan user:

Untuk menjamin bahwa seluruh transaksi terotorisasi, valid, dicatat secara akurat, benar dan lengkap.

Pengendalian internal dalam aplikasi SIMDA Keuangan yaitu dengan adanya pembagian tingkat kewenangan, yang meliputi: administrator, supervisor, dan operator.

Administrator memiliki kewenangan untuk membuat user dan melakukan setting pada otoritas user, melaukukan setting pada aplikasi (parameter), melakukan posting anggaran, dan melakukan unposting pada jurnal. 
Supervisor memiliki kewenangan untuk melakukan otorisasi pada penginputan data serta melakukan koreksi dan penyesuaian.

Operator hanya memiliki kewenangan untuk melakukan input data serta melihat laporan.

b) Pengendalian menu berdasarkan Fungsi bertujuan untuk menjamin validitas input atas data aplikasi SIMDA Keuangan yang mengatur pengendalian berdasarkan fungsi penganggaran, fungsi penatausahaan, dan fungsi pembukuan.

\section{Kesimpulan}

Pengelolaan keuangan daerah adalah hal vital untuk mewujudkan pemerintahan daerah yang bersih dan akuntabel, tanpa adanya SDM yang berkompetensi dan pemantauan berkelanjutan pengelolaan keuangan daerah tidak bisa dilakukan dengan baik. Dengan berkembangnya teknologi dan informasi, manusia terus berupaya untuk membuat semua hal menjadi lebih mudah termasuk juga dalam pengelolaan keuangan, maka dibuatlah aplikasi pengelolaan keuangan daerah untuk memudahkan dan juga mengontrol pengeluaran daerah selama setahun penuh. Banyak aplikasi pengelolaan keuangan daerah yang beredar di Indonesia, namun yang dijadikan studi adalah aplikasi SIMDA. Penginputan dan alur pada SIMDA mengacu pada Permendagri Pedoman Pengelolaan Keuangan Daerah, alur yang dipakai yaitu dari penganggaran yakni penginputan Renstra dan RKA sampai jadi DPA, lalu ke Penatausahaan yang mengatur pengeluaran keuangan daerah dengan penerbitan SPP, SPM dan SP2D, dan yang terakhir untuk menghasilkan pelaporan yang komprehensif dan terintegrasi dilakukan penginputan jurnal, saldo awal serta pendapatan sehingga tercipta laporan keuangan yang lengkap dan dapat di komparasi. Untuk SIMDA BMD berpedoman pada Permendagri Nomor 19 tahun 2016 tentang Pedoman Pengelolaan Barang Milik Daerah dimana sudah mengakomodir Perencanaan Aset, Pengadaan Aset, Penatausahaan Aset, Penghapusan Aset dan Akuntansi.

Aplikasi SIMDA Keuangan dan BMD membantu Pemerintah Daerah menyusun Laporan Keuangan dan Laporan Aset melalui media teknologi informasi, dengan proses otomatisasi yang terdapat dalam aplikasi serta dengan pengendalian aplikasi yang baik sehingga kesalahan dalam pembuatan Laporan Keuangan dan Laporan aset dapat diminimalisir, pada akhirnya akan menciptakan Laporan Keuangan Pemerintah Daerah yang andal, transparan dan akuntabel.

Sebaik apapun aplikasi tentunya tergantung pula pada SDM yang mengoperasikannya, sehingga diharapkan pemerintah daerah dapat melatih SDM-nya agar menjadi SDM yang unggul serta diharapkan juga kedepannya agar aplikasi pengelolaan keuangan daerah dapat terus berkembang secara dinamis sesuai dengan Undang-Undang dan peraturan baru yang nantinya akan muncul. 


\section{BIBLIOGRAFI}

Ananda, Febryandhie, \& Sari, Mustika Permata. (2020). Pengaruh Implementasi Sistem Informasi Manajemen Daerah (SIMDA) Keuangan Terhadap Kualitas Laporan Keuangan (Studi pada Lingkungan Dinas Kesehatan Kabupaten Padang Pariaman). Jurnal Pundi, 4(2). Google Scholar

Ariska, Cici, Masniadi, Rudi, \& Rachman, Rosyidah. (2019). Penerapan Sistem Informasi Manajemen Daerah (Simda) Terhadap Kualitas Laporan Keuangan Skpd Di Kabupaten Sumbawa. Jurnal Riset Kajian Teknologi Dan Lingkungan, 2(1), 15-23. Google Scholar

BPKP. (2011). Modul Bimbingan Teknis Pedoman Pengoperasian Simda Keuangan. Jakarta: Deputi Pengawasan Bidang Penyelenggaraan Keuangan Daerah. Google Scholar

Darea, Devita Wulandari, \& Elim, Inggriani. (2015). Evaluasi Penerapan Sistem Informasi Manajemen Daerah (SIMDA) Keuangan pada DPPKA Kabupaten Kepulauan Sangihe. Jurnal EMBA: Jurnal Riset Ekonomi, Manajemen, Bisnis Dan Akuntansi, 3(2), 114-122. Google Scholar

Hardjanto, Kurnia. (2019). Implementasi Sistem Informasi Manajemen Daerah (Simda) Keuangan Berbasis Akrual Pada Dinas Pertanian Dan Pangan Kota Magelang. Jurnal Teknik Informatika, 12(1), 11-20. Google Scholar

Inayah, Restu, Hakiki, Arista, \& Relasari, Relasari. (2016). Analisis Sistem Informasi Manajemen Daerah (Simda) Keuangan pada Dinas Pendapatan, Pengelolaan Keuangan dan Aset Daerah (Ppkad) Kabupaten Lahat. Akuntabilitas, 10(2), 167176. Google Scholar

Nugraha, Harmadhani Adi. (2013). Analisis Penerapan Sistem Informasi Manajemen Keuangan Daerah (SIMDA Keuangan) Dalam Pengolahan Data Keuangan Pada Organisasi Pemerintah Daerah (Studi Kasus Pada Dinas Kesehatan Kabupaten Nganjuk. SKRIPSI Jurusan Akutansi-Fakultas Ekonomi UM, 2(1), 23-33. Google Scholar

Polii, Imanuel Ronaldo Angelo, \& Pontoh, Winston. (2018). Ipteks pengendalian intern SIMDA keuangan dalam pengelolaan data keuangan pada Badan Perencanaan Dan Pembangunan Daerah (BAPPEDA) Provinsi Sulawesi Utara. Jurnal Ipteks Akuntansi Bagi Masyarakat, 2(2). Google Scholar

Sugiyono, Sugiyono. (2010). Metode penelitian kuantitatif dan kualitatif dan R\&D. Alfabeta Bandung. Google Scholar

Sultan, Mahayuddin, \& Fatimah, Jenny Maria. (2016). Evaluasi Sistem Informasi Manajeman Barang Milik Daerah (Simda-bmd) dalam Mendukung Inventarisasi Aset Daerah di Kabupaten Majene. KAREBA: Jurnal Ilmu Komunikasi, 118-129. Google Scholar 
Utami, Annafia, \& Sari, Yeni Priatna. (2017). Analisis Efektivitas Penggunaan Sistem Informasi Manajemen Daerah (Simda)-Barang Milik Daerah (Bmd) Pada Dppkad Kabupaten Pemalang. Monex: Journal of Accounting Research-Politeknik Harapan Bersama Tegal, 6(1). Google Scholar

Watulingas, Patricia, \& Tangkuman, Steven. (2018). Ipteks Aplikasi Sistem Informasi Manajemen Daerah (Simda) Keuangan Pada Badan Perencanaan Dan Pembangunan Daerah Provinsi Sulawesi Utara. Jurnal Ipteks Akuntansi Bagi Masyarakat, 2(2). Google Scholar

Yanto, Edi, \& Afkir, Mr. (2020). ANALISIS PENERAPAN SISTEM INFORMASI MANAJEMEN KEUANGAN DAERAH (SIMDA KEUANGAN) DALAM PENGOLAHAN DATA KEUANGAN PADA ORGANISASI PEMERINTAH DAERAH (Studi Kasus Pada Dinas Lingkungan Hidup Kabupaten Tolitoli). Indonesian Journal of Strategic Management, 3(1). Google Scholar

\section{Copyright holder:}

Andhika Ramanda, Safuan, Musa Alkadhim Alhabshy (2021)

First publication right:

Syntax Literate: Jurnal Ilmiah Indonesia

This article is licensed under:

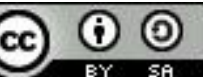

